\title{
Family history of thyroid disease and risk of congenital hypothyroidism in neonates with Down syndrome
}

\author{
Jorge R. Corona-Rivera, ${ }^{1,2 *}$ Topacio O. Andrade-Romo, ${ }^{1}$ Liuba M. Aguirre-Salas, ${ }^{3}$ Lucina Bobadilla-Morales, ${ }^{1,2}$ \\ Cristian I. Aranda-Sánchez, ${ }^{1}$, Alfredo Corona-Rivera ${ }^{1,2}$ and René O. Pérez-Ramírez ${ }^{4}$ \\ ${ }^{1}$ Department of Genetics and Cytogenetics Unit, Pediatrics Division, Congenital Anomalies Registration and Research Center, Hospital Civil de \\ Guadalajara "Dr. Juan I. Menchaca"; 'Department of Molecular Biology and Genomics, Health Sciences University Center, Instituto de Genética Humana \\ "Dr. Enrique Corona-Rivera", Universidad de Guadalajara; ${ }^{3}$ Endocrinology Department, Pediatrics Division, Hospital Civil de Guadalajara "Dr. Juan I. \\ Menchaca"; "Neonatology Department, Pediatrics Division, Hospital Civil de Guadalajara "Dr. Juan I. Menchaca". Guadalajara, Jalisco, Mexico
}

\begin{abstract}
Introduction: Family history of thyroid disease (FHTD) constitutes a possible risk factor for congenital hypothyroidism (CH) in the general population; however, FHTD possible relationship with $\mathrm{CH}$ in subjects with Down syndrome (DS) has not yet been explored. Objective: To determine whether FHTD is associated with an increased incidence of $\mathrm{CH}$ in neonates with DS. Method: Hospital-based case-control study in 220 neonates with DS. Thyroid function tests of 37 infants with DS and positive FHTD (cases) were compared with those of 183 newborns with DS without FHTD (control group). Data were analyzed using multivariate logistic regression analysis and adjusted odds ratios (aORs) with their respective $95 \%$ confidence intervals (Cl) were calculated. Results: Nine newborns with DS in our sample had $\mathrm{CH}(4.1 \%)$. In the multivariate analysis, FHTD showed an association with $\mathrm{CH}$ in neonates with $\mathrm{DS}(\mathrm{aOR}=8.3,95 \% \mathrm{Cl}: 2.0-34.3)$, particularly in males (aOR $=9.0,95 \% \mathrm{Cl}$ : 1.649.6). In contrast, newborns with DS without FHTD were less likely to suffer from $\mathrm{CH}$ (aOR $=0.4,95 \% \mathrm{Cl}: 0.1-0.8)$. Conclusions: Newborns with DS and FHTD have an eight-fold higher risk for $\mathrm{CH}$, particularly when the index case is male. FHTD detailed evaluation can be an easy and accessible strategy to identify those newborns with DS at higher risk for $\mathrm{CH}$.
\end{abstract}

KEY WORDS: Down syndrome. Congenital hypothyroidism. TSH. Free T4. Family history of thyroid disease.

\section{Historia familiar de enfermedad tiroidea y riesgo de hipotiroidismo congénito en neonatos con síndrome de Down}

\section{Resumen}

Introducción: La historia familiar de enfermedad tiroidea (HFET) como factor de riesgo para hipotiroidismo congénito (HC), en síndrome de Down (SD) aún no ha sido explorada. Objetivo: Determinar si la HFET está asociada a mayor riesgo de $H C$ en neonatos con SD. Método: Estudio de casos y controles en 220 neonatos con SD. Se compararon las pruebas de función tiroidea (PFT) de 37 con SD e HFET (casos), frente a las PFT de 183 recién nacidos con SD sin HFET (grupo de referencia). Se realizó análisis de regresión logística multivariante y se calculó la razón de momios (RM) y sus respectivos intervalos de confianza del 95 \% (IC $95 \%$ ). Resultados: Nueve casos HC (4.1\%). El HC mostró asociación con la HFET (RMa = 8.3, IC $95 \%$ : 2.0-34.3), particularmente en los varones (RMa = 9.0, IC $95 \%: 1.6-49.6)$. La ausencia de HFET tuvo una RM de protección para HC (RMa = 0.4, IC $95 \%$ : 0.1-0.8). Conclusiones: La HFET puede es una estrategia fácil y accesible para identificar pacientes con SD con mayor riesgo de $H C$.

PALABRAS CLAVE: Síndrome de Down. Hipotiroidismo congénito. TSH. T4 libre. Historia familiar de enfermedad tiroidea.

\footnotetext{
Correspondence:

Date of reception: 24-03-2020

*Jorge R. Corona-Rivera

E-mail: rocorona@cucs.udg.mx

Date of acceptance: $27-08-2020$

DOI: $10.24875 / G M M . M 21000538$

0016-3813/@ 2020 Academia Nacional de Medicina de México, A.C.. Published by Permanyer. This is an open access article under the CC BY-NC-ND license (http://creativecommons.org/licenses/by-nc-nd/4.0/)

Gac Med Mex. 2021;157:133-139

Contents available at PubMed

www.gacetamedicademexico.com
} 


\section{Introduction}

Patients with Down syndrome (DS) have an increased risk of congenital hypothyroidism $(\mathrm{CH})$. Tests to detect $\mathrm{CH}$ at birth are recommended for all newborns (NBs) with DS. ${ }^{1}$ In screening programs, 1-2 \% of NBs with DS are detected with $\mathrm{CH}$, which is equivalent to 1 out of every 141 NBs with DS, a proportion 28 times higher than that observed in the general population. ${ }^{2-4}$ In addition to $\mathrm{CH}$, thyroid function tests (TFT) often also detect subclinical hypothyroidism and/or changes in plasma levels of thyroid stimulating hormone (TSH) and thyroxine (T4), all of thyroid origin. ${ }^{5}$ Trisomy 21 has been suggested to be the cause of imbalances in dose-sensitive genes (such as IFNAR1 and IFNAR2), thus interfering with thyroid hormone production or thyroid ontogenesis. ${ }^{6}$ However, susceptibility factors other than trisomy 21 may be involved.

Autoimmunity is strongly implicated in the occurrence of Hashimoto's thyroiditis, or Graves' disease in older children and adults with DS, ${ }^{4,7}$ but not in that of $\mathrm{CH}$, which is considered a non-autoimmune disorder. ${ }^{5,6}$ More 50 years ago, Fialkow et al. ${ }^{8}$ observed an increase in the frequency of thyroid antibodies in mothers of neonates with DS, with evidence of a clear association between DS and thyroid disease in newborns; however, they did not investigate neonatal thyroid function. Family history of thyroid disease (FHTD) has been described as a risk factor for $\mathrm{CH}$ in children without malformations. ${ }^{9}$ However, the possible relationship of FHTD with $\mathrm{CH}$ in DS has not yet been explored. In a previous study, ${ }^{10}$ we observed that FHTD was 2.3-fold higher among NBs with DS with regard to a control group of NBs without malformations. The purpose of the present work was to investigate whether FHTD increases the risk of $\mathrm{CH}$ among NBs with DS compared to a reference group of NBs with DS and without FHTD.

\section{Method}

From January 2009 to December 2018, we conducted a case-control study in 220 NBs with DS, including 37 NBs with DS and FHTD (cases) and 183 NBs with DS without FHTD (reference group), all born at Hospital Civil de Guadalajara "Dr. Juan I. Menchaca" (Guadalajara, Jalisco, Mexico). Data were collected by the Congenital Anomalies Registration and Research Center (CRIAC - Centro de Registro e Investigación de Anomalías Congénitas), our hospital program in charge of congenital defects surveillance, which includes all live births $\geq 20$ weeks of gestation and weighing $\geq 500 \mathrm{~g}$. Only patients with trisomy $21 \mathrm{di}-$ agnosis confirmed by peripheral blood karyotype determination in our cytogenetics unit, and who also had TSH and T4 measurements carried out during the neonatal period, were included. Patients who did not have TFTs or in whom these were incomplete were excluded. The study was approved by the Hospital Civil de Guadalajara "Juan I. Menchaca" Ethics Committee, and the ethical standards established in the Declaration of Helsinki of 1964 and subsequent amendments were followed. Approval was granted by the Research Ethics Board of the Jalisco Ministry of Health (\# 0116/16 HCJM/2016).

TSH and T4 determinations were made at a mean age of 10.9 days at the time of the study ( $66 \%$ between the third and tenth day of life). T4 was measured as free T4, total T4 or both, depending on availability in the laboratory at our hospital. None of our patients had received treatment for hypothyroidism before obtaining the samples for TFTs. TSH, free T4 and total T4 concentrations were determined according to the operating procedures standards in our central laboratory. All samples were analyzed on a UniCel $^{\mathrm{TM}}$ Dxl 800 immunoassay system with automated access (Beckman Coulter Inc., Brea, CA, USA), using a direct chemiluminescence detection system according to the manufacturer's instructions.

TFT results were interpreted using standardized reference intervals specific for the age at the time the sample was taken. ${ }^{11,12}$ TFT results were classified according to Jonklaas et al. ${ }^{13}$ as: 1) Primary $\mathrm{CH}$, elevated $\mathrm{TSH}$ with low free T4 and/or total T4 with regard to reference intervals; 2) hyperthyrotropinemia, high TSH with free $\mathrm{T} 4$ and/or total T4 within reference intervals; 3) euthyroid sick syndrome, low TSH and free T4 and/ or total T4, all below the reference interval, and 4) euthyroid, normal TSH, free T4 and total T4.

The registry used by CRIAC was obtained by interviewing the mothers of babies with DS shortly after birth, after written informed consent to participate in the study and to allow the review of the medical record was obtained. Family history was obtained in all patients using the three-generation family tree method. ${ }^{14}$ NBs with DS from families with one or more members affected by any thyroid disease constituted the group of cases, and those with a negative FHTD, the reference group. The collected family history included specific questions and details regarding the presence and 
type of thyroid disease among the relatives of the index case. Other potential $\mathrm{CH}$ risk factors were also evaluated, ${ }^{15}$ including: maternal age $\geq 35$ years, parity $\geq 4$ and presence of diabetes during pregnancy, as well as self-reported tobacco and alcohol consumption during pregnancy. The route of delivery, gender of the newborn, gestational age, birth weight $(<2,000 \mathrm{~g}), 5$-min Apgar score $<7$, and presence of congenital heart defects and/or gastrointestinal malformations were also recorded.

$\mathrm{TSH}$, free T4 and total T4 mean values \pm standard error were compared using Mann-Whitney' U-test, since they did not follow a normal distribution according to Kolmogorov-Smirnov's test. Maternal characteristics and NBs variables were compared between NBs with DS and those of the reference group using the chi-square test; a $p$-value $<0.05$ was considered to be statistically significant. The factors that showed statistical differences between the study groups were included in a multivariate logistic regression analysis to evaluate the deviation explained by the different variables of interest using the enter method and expressed as adjusted OR (aOR) with its respective 95 $\%$ confidence intervals $(\mathrm{Cl})$. Data analysis was carried out using the SPSS program (IBM SPSS Statistics, Version 21.0; IBM Corp.; Armonk, NY, USA).

\section{Results}

Of a total of 269 patients born with DS in our hospital during the study period, $220(81.8 \%)$ met the inclusion criteria (206 with complete trisomy 21,8 with mosaic trisomy 21 , and 6 with translocation trisomy), with 49 who had incomplete TFT and/or no confirmation by karyotype being excluded. Thirty-seven patients (16.8\%) with DS and FHTD (group of cases) were compared with 183 patients with DS (83.2\%) and negative FHTD (reference group); 126 NBs were males $(57.3 \%)$ and 94 were females (42.7\%), with a male: female ratio of 1.3:1.

Table 1 shows the FHTD obtained for the 37 families of the group of cases. Only seven index cases had a history of a first-degree relative with thyroid disease (mother or sister) and, in most families, the referred affected subject had a second or third degree kinship relationship. In each index case, the number of relatives affected with thyroid disease was one, two, and three or more in 24,11 , and 3 , respectively. Hypothyroidism $(n=30)$ was the most commonly reported thyroid disease in most these families, but they also
Table 1. History of thyroid disease in $\mathbf{3 7}$ families of neonates with Down syndrome

\begin{tabular}{|c|c|}
\hline Family history of thyroid disease & $\begin{array}{l}\text { Number of } \\
\text { families }\end{array}$ \\
\hline Mother with hypothyroidism & 4 \\
\hline Sister with hypothyroidism & 3 \\
\hline At least one second-degree relative affected & 19 \\
\hline At least one third-degree relative affected & 18 \\
\hline At least one relative affected on the maternal side & 25 \\
\hline At least one relative affected on the paternal side & 11 \\
\hline At least one relative affected within the family & 4 \\
\hline $\begin{array}{l}\text { Type of thyroid disease in the family } \\
\text { Hypothyroidism } \\
\text { Hyperthyroidism } \\
\text { Goiter } \\
\text { Thyroid disease, not specified }\end{array}$ & $\begin{array}{c}30 \\
4 \\
2 \\
4\end{array}$ \\
\hline $\begin{array}{l}\text { Number of affected relatives } \\
\text { One } \\
\text { Two } \\
\text { Three or more }\end{array}$ & $\begin{array}{c}24 \\
11 \\
3\end{array}$ \\
\hline
\end{tabular}

reported hyperthyroidism $(n=4)$, goiter $(n=2)$, and unspecified thyroid disease $(n=4)$.

Table 2 shows the potential risk factors for $\mathrm{CH}$ in relation to the presence of FHTD in the study sample. There was a larger number of female affected subjects in the group of cases in comparison with the reference group (OR $=2.3,95 \% \mathrm{Cl}: 1.1-4.6, \mathrm{p}=0.029)$, while, in the reference group, male affected subjects were predominant $(\mathrm{OR}=0.4,95 \% \mathrm{Cl}$ : 0.2-0.9, $p=0.029$ ). For the rest of characteristics evaluated between the study groups, no other statistical differences were found in the bivariate analysis.

Table 3 shows TFT mean values compared to FHTD. Mean free T4 was lower in the group of cases than in the reference group $(p=0.004)$. No other significant differences were found. Thyroid diagnoses according to the presence of FHTD and their crude and adjusted ORs are presented in table 4. OR was adjusted for gender. Nine NBs with DS in our study sample had $\mathrm{CH}(4.1 \%)$, all of them with $\mathrm{TSH}$ $>10 \mu \mathrm{lU} / \mathrm{mL}$, free $\mathrm{T} 4>0.9 \mathrm{ng} / \mathrm{dL}$ and/or total $\mathrm{T} 4$ $<7.2 \mu \mathrm{g} / \mathrm{dL}$. In addition, 37 had hyperthyrotropinemia (16.8\%), four had euthyroid sick syndrome $(1.8 \%)$ and the rest were classified according to the TFT result as normal $(77.3 \%)$. The multivariate analysis showed that $\mathrm{CH}$ was associated with FHTD in NBs with DS $(\mathrm{aOR}=8.3,95 \% \mathrm{Cl}: 2.0-34.3)$, particularly in male 
Table 2. Maternal characteristics and pregnancy outcome in relation to family history of thyroid disease among neonates with Down syndrome of the study sample

\begin{tabular}{|c|c|c|c|c|}
\hline \multirow[t]{3}{*}{ Variables } & \multicolumn{2}{|c|}{ Family history of thyroid disease } & \multirow[t]{3}{*}{$\mathbf{p}^{*}$} & \multirow[t]{3}{*}{ OR $(95 \%$ Cl) } \\
\hline & Positive & Negative & & \\
\hline & $\mathrm{n}=37(\%)$ & $n=183(\%)$ & & \\
\hline $\begin{array}{l}\text { Family history } \\
\text { Consanguinity } \\
\text { Relatives with congenital heart disease } \\
\text { Relatives with Down syndrome }\end{array}$ & $\begin{array}{l}1(2.7) \\
4(10.8) \\
9(24.3)\end{array}$ & $\begin{array}{c}4(2.2) \\
14(7.6) \\
41(22.4)\end{array}$ & $\begin{array}{l}1.000 \\
0.514 \\
0.831\end{array}$ & $\begin{array}{l}1.2(0.1-11.4) \\
1.5(0.4-4.7) \\
1.1(0.5-2.5)\end{array}$ \\
\hline $\begin{array}{l}\text { Maternal characteristics } \\
\text { Maternal age (years, mean } \pm \mathrm{SD} \text { ) } \\
\leq 19 \text { years } \\
\geq 35 \text { years }\end{array}$ & $\begin{array}{c}29.5 \pm 8.7 \\
6(16.2) \\
11(29.7)\end{array}$ & $\begin{array}{l}29.9 \pm 9.2 \\
36(19.7) \\
71(38.8)\end{array}$ & $\begin{array}{l}0.785^{\dagger} \\
0.819 \\
0.354\end{array}$ & $\begin{array}{l}0.8(0.3-2.0) \\
0.7(0.3-1.4)\end{array}$ \\
\hline Low socioeconomic level & $8(21.6)$ & $50(27.3)$ & 0.544 & $0.7(0.3-1.7)$ \\
\hline Nulliparous & $9(24.3)$ & $52(28.4)$ & 0.691 & $0.8(0.4-1.8)$ \\
\hline Parity $\geq 4$ & $15(40.5)$ & $68(37.1)$ & 0.713 & $1.1(0.6-2.4)$ \\
\hline $\begin{array}{l}\text { Pre-gestational BMl }\left(\mathrm{kg} / \mathrm{m}^{2} \text {, mean } \pm \mathrm{SD}\right)^{\ddagger} \\
\quad<18.5 \mathrm{~kg} / \mathrm{m}^{2} \\
\geq 25 \mathrm{~kg} / \mathrm{m}^{2} \\
\geq 30 \mathrm{~kg} / \mathrm{m}^{2}\end{array}$ & $\begin{array}{c}26.1 \pm 4.7 \\
1(2.8) \\
18(51.4) \\
7(20.0)\end{array}$ & $\begin{array}{c}25.7 \pm 5.1 \\
5(3.3) \\
70(45.8) \\
32(20.9)\end{array}$ & $\begin{array}{l}0.674^{+} \\
1.000 \\
0.577 \\
1.000\end{array}$ & $\begin{array}{l}0.9(0.1-7.7) \\
1.2(0.6-2.6) \\
0.9(0.4-2.4)\end{array}$ \\
\hline $\begin{array}{l}\text { Gestational weight gain }(\mathrm{kg} \text {, mean } \pm \mathrm{SD})^{\ddagger} \\
\text { Insufficient } \\
\text { Adequate } \\
\text { Excessive }\end{array}$ & $\begin{array}{l}8.7 \pm 5.5 \\
20(57.1) \\
8(22.8) \\
7(20.0)\end{array}$ & $\begin{array}{l}9.0 \pm 6.8 \\
67(43.8) \\
61(39.9) \\
25(16.3)\end{array}$ & $\begin{array}{c}0.778^{\dagger} \\
0.190 \\
0.079^{\ddagger} \\
0.622\end{array}$ & $\begin{array}{l}1.7(0.8-3.5) \\
0.4(0.2-1.0) \\
1.3(0.5-3.2)\end{array}$ \\
\hline Gestational diabetes & $1(2.7)$ & $14(7.7)$ & 0.476 & $0.3(0.0-2.6)$ \\
\hline Tobacco consumption during pregnancy & $7(18.9)$ & $26(14.2)$ & 0.455 & $1.4(0.6-3.5)$ \\
\hline Alcohol consumption during pregnancy & $6(16.2)$ & $26(14.2)$ & 0.798 & $1.2(0.4-3.1)$ \\
\hline Vaginal delivery & $13(35.1)$ & $78(42.6)$ & 0.466 & $0.7(0.3-1.5)$ \\
\hline Cesarean section delivery & $22(59.4)$ & $100(54.6)$ & 0.717 & $1.2(0.6-2.5)$ \\
\hline $\begin{array}{l}\text { Newborns } \\
\text { Females } \\
\text { Males }\end{array}$ & $\begin{array}{l}22(59.5) \\
15(40.5)\end{array}$ & $\begin{array}{l}72(39.3) \\
111(60.7)\end{array}$ & $\begin{array}{l}0.029 \\
0.029\end{array}$ & $\begin{array}{l}2.3(1.1-4.6) \\
0.4(0.2-0.9)\end{array}$ \\
\hline $\begin{array}{l}\text { Gestational age (weeks, mean } \pm \text { SD) } \\
\text { Preterm birth }\end{array}$ & $\begin{array}{c}37.4 \pm 2.2 \\
10(27.0)\end{array}$ & $\begin{array}{c}37.5 \pm 1.9 \\
50(27.3)\end{array}$ & $\begin{array}{c}0.740^{+} \\
1.000\end{array}$ & $0.9(0.4-2.2)$ \\
\hline Length (cm, mean $\pm \mathrm{SD}$ ) & $46.7 \pm 3.9$ & $46.8 \pm 3.0$ & $0.744^{\dagger}$ & \\
\hline $\begin{array}{l}\text { Weight }(\mathrm{g}, \text { mean } \pm \mathrm{SD}) \\
\text { Small for gestational age } \\
\text { Weight }<2,000 \mathrm{~g}\end{array}$ & $\begin{array}{l}2501 \pm 623 \\
9(24.3) \\
7(18.9)\end{array}$ & $\begin{array}{l}2591 \pm 619 \\
37(20.2) \\
37(20.2)\end{array}$ & $\begin{array}{l}0.421^{\dagger} \\
0.658 \\
1.000\end{array}$ & $\begin{array}{l}1.3(0.5-2.9) \\
0.9(0.4-2.2)\end{array}$ \\
\hline Head circumference $(\mathrm{cm}$, mean $\pm \mathrm{SD})$ & $31.6 \pm 2.0$ & $31.7 \pm 3.6$ & $0.817^{\dagger}$ & \\
\hline 1-min Apgar < 7 & $6(16.2)$ & $39(21.3)$ & 0.655 & $0.7(0.3-1.8)$ \\
\hline 5-min Apgar < 7 & $2(5.4)$ & $12(6.6)$ & 1.000 & $0.8(0.2-3.8)$ \\
\hline Congenital heart disease & $12(32.4)$ & $72(39.3)$ & 0.464 & $0.7(0.3-1.6)$ \\
\hline Gastrointestinal malformation & $2(5.4)$ & $15(8.2)$ & 0.744 & $0.6(0.1-2.9)$ \\
\hline
\end{tabular}

* Chi-square test result for both columns.

† Student's t-test.

¥ Available for 35 and 153 mothers of the group of cases and reference group, respectively.

$\mathrm{OR}=$ odds ratio; $\mathrm{Cl}=$ confidence interval; $\mathrm{SD}=$ standard deviation. 
Table 3. Thyroid function tests in neonates with Down syndrome according to family history of thyroid disease

\begin{tabular}{|c|c|c|c|c|c|}
\hline \multirow[t]{3}{*}{ Variables } & \multicolumn{4}{|c|}{ Family history of thyroid disease } & \multirow[t]{3}{*}{$\mathbf{p}^{*}$} \\
\hline & \multicolumn{2}{|c|}{ Positive } & \multicolumn{2}{|c|}{ Negative } & \\
\hline & $\mathrm{n}$ & Mean \pm SD (range) & n & Mean \pm SD (range) & \\
\hline Age at diagnosis (days) & 37 & $12.3 \pm 8.1(4-30)$ & 183 & $10.6 \pm 7.9(3-30)$ & 0.241 \\
\hline $\mathrm{TSH}(\mu \mathrm{U} / \mathrm{mL})$ & 37 & $10.99 \pm 16.3(1.2-95.4)$ & 183 & $6.82 \pm 6.7(0.2-54.3)$ & 0.011 \\
\hline Free T4 (ng/dL) & 26 & $1.11 \pm 0.4(0.5-2.1)$ & 115 & $1.54 \pm 1.1(0.5-11.6)$ & 0.058 \\
\hline Total T4 ( $\mu \mathrm{g} / \mathrm{mL})$ & 29 & $9.36 \pm 2.7(2.8-17.4)$ & 126 & $9.20 \pm 3.3(0.7-16.6)$ & 0.818 \\
\hline
\end{tabular}

$\mathrm{SD}=$ standard deviation; $\mathrm{TSH}=$ thyroid-stimulating hormone; $\mathrm{T} 4$ = thyroxin.

*Student's t-test.

Table 4. Diagnoses based on thyroid tests in neonates with Down syndrome according to family history of thyroid disease

\begin{tabular}{|l|c|c|c|c|}
\hline \multirow{2}{*}{ Variables } & \multicolumn{2}{|c|}{ Family history of thyroid disease } & \multicolumn{2}{|c|}{ Odds ratio } \\
\cline { 2 - 5 } & Positive $n=37(\%)$ & Negative $n=183(\%)$ & Crude (95\% Cl) & Adjusted* (95\% Cl) \\
\hline Euthyroid & $23(62.2)$ & $147(80.3)$ & $0.4(0.2-0.8)$ & $0.4(0.1-0.8)$ \\
\hline Congenital hypothyroidism & $5(13.5)$ & $4(2.2)$ & $6.9(1.8-27.4)$ & $8.3(2.0-34.3)$ \\
\hline Subclinical hypothyroidism & $9(24.3)$ & $28(15.3)$ & $1.8(0.8-4.2)$ & $1.8(0.8-4.3)$ \\
\hline Euthyroid sick syndrome & $0(0)$ & $4(2.2)$ & $0.9(0.1-8.7)^{\dagger}$ & $1.3(0.1-11.5)^{\dagger}$ \\
\hline Congenital hypothyroidism in girls & $2(5.4)$ & $1(0.5)$ & $10.4(0.9-117.8)$ & $7.1(0.6-86.4)$ \\
\hline Congenital hypothyroidism in boys & $3(8.1)$ & $3(1.6)$ & $5.3(1.0-27.3)$ & $9.0(1.6-49.6)$ \\
\hline Subclinical hypothyroidism in girls & $6(16.2)$ & $10(5.5)$ & $3.3(1.1-9.9)$ & $2.3(0.7-7.3)$ \\
\hline Subclinical hypothyroidism in boys & $3(8.1)$ & $18(9.8)$ & $0.8(0.2-2.9)$ & $1.3(0.3-5.0)$ \\
\hline
\end{tabular}

$\mathrm{Cl}=$ confidence interval

*Odds ratio was adjusted according to infants' gender.

tEstimated according to Haldane-Anscombe $1 / 2$ correction.

NBs (aOR $=9.0,95 \% \mathrm{Cl}: 1.6-49.6)$. Negative FHTD was a protective factor for $\mathrm{CH}$ in NBs with DS $(\mathrm{aOR}=0.4,95 \% \mathrm{Cl}: 0.1-0.8)$. Only one of the infants with $\mathrm{CH}$ was born to a hypothyroid mother and none of the NBs had hyperthyrotropinemia. For the rest of the evaluated variables, aORs showed no effect on the study variables.

\section{Discussion}

This study used venous TFT for several reasons: a) NBs with DS constitute a population at high risk for $\mathrm{CH}, \mathrm{b})$ screening for $\mathrm{CH}$ is not universally practiced in Mexico, ${ }^{16} \mathrm{c}$ ) there are difficulties in our institution for quickly and efficiently having access to screening program results, and d) TFT results are available within the same day in our hospital laboratory.
Even so, the frequency of $\mathrm{CH}$ of $4 \%$ in our cohort of NBs with DS is consistent with reports of previous studies, despite the fact that most of them are derived from screening programs in NBs. ${ }^{1-4,6,17-19}$ In addition, our results support that thyroid dysfunction in NBs with DS is usually not severe, with mild $\mathrm{CH}$ and, more often, a high prevalence of hyperthyrotropinemia being observed (Table 4). These particularities of thyroid function in DS have been attributed to a probable innate error in the metabolism of thyroid hormones or to immaturity of the hypothalamic-pituitary axis. ${ }^{18}$

Our study group was similar to others previously published with regard to common comorbidities in DS and also for other possible risk factors for $\mathrm{CH}$ that are applicable to the general population, ${ }^{4,17}$ except for the differences in NBs gender (Table 2). 
Through multivariate analysis, an increased risk for $\mathrm{CH}$ was identified in NBs with DS and FHTD, and as protective factor, negative FHTD. Risk is particularly high in male patients with DS (Table 4). This association has not been previously reported. This suggests that family history can be regarded as a risk factor for certain susceptible genotypes. ${ }^{20} \mathrm{CH}$ clustering in members of families with DS may be explained by shared genetic factors. Therefore, this study strongly suggests that there is a subgroup of DS patients with a higher risk for $\mathrm{CH}$.

History of thyroid problems in mothers or fathers of newborns with $\mathrm{CH}$ is considered a risk factor for $\mathrm{CH}$ in the general population, ${ }^{9}$ with a clear relationship between FHTD and $\mathrm{CH}$ being observed. In the study by Underland et al. ${ }^{21}$, however, said association was found only in a bivariate analysis, and a positive FHTD was restricted only to the parents. Although the exact explanation for the association between FHTD and $\mathrm{CH}$ remains unknown, autoimmune pathogenesis seems unlikely. In infants without malformations, less than $3 \%$ of cases with $\mathrm{CH}$ result from maternal autoimmune disease related to TSH-inhibiting antibodies. ${ }^{8,21}$ In our study, autoimmune etiology was not evaluated, but it also seems unlikely for it to explain the association between FHTD and $\mathrm{CH}$ in our neonates with DS, since only one of the studied infants with $\mathrm{CH}$ had a hypothyroid mother. In any case, thyroid disease familial aggregation reveals a genetic predisposition for $\mathrm{CH}$ in DS, but this will necessarily require subsequent confirmation, including evaluation using other genetic markers. The finding of a higher risk of $\mathrm{CH}$ in males with DS and positive HFET is not easy to explain (Table 4). The female gender has been clearly identified as a risk factor for $\mathrm{CH}$ in the general population. ${ }^{3,9,22}$ However, in DS, the proportion of each gender affected by $\mathrm{CH}$ has not been unequivocally identified. ${ }^{2,3,5}$ Therefore, future research is required to explain the observed gender difference.

As a limitation inherent to the case-control design that was used, memory bias cannot be excluded, since the information was obtained by means of interviews and self-reports. Not having determined $\mathrm{CH}$ etiology (dyshormonogenesis or dysgenesis) and not having a hypothyroidism follow-up in our patients also constitute additional weaknesses in our study. Furthermore, the number of our patients with FHTD was relatively small, thus indicating the need for future studies or a meta-analysis of several published reports.
In conclusion, we confirmed the association between $\mathrm{CH}$ and FHTD in NBs with DS. Infants with DS and FHTD have an eight-fold higher risk of $\mathrm{CH}$, particularly those of the male gender. FHTD assessment using a three-generation family tree is an easy and accessible strategy to identify infants at higher risk of $\mathrm{CH}$ among the population of NBs with DS and should not be underestimated. However, the intrinsic causal mechanisms of this relationship remain, so far, unknown.

\section{Acknowledgments}

We would like to thank the CRIAC team for their enthusiastic operational support. We also thank the staff of our cytogenetics unit for their valuable assistance for chromosomal analysis.

\section{Conflict of interests}

The authors declare that they have no conflicts of interest.

\section{Funding}

The authors did not receive any sponsoring to carry out this article.

\section{Ethical disclosures}

Protection of human and animal subjects. The authors declare that no experiments were performed on humans or animals for this research.

Confidentiality of data. The authors declare that they have followed the protocols of their work center on the publication of patient data.

Right to privacy and informed consent. The authors have obtained informed consent from the patients and/or subjects referred to in the article. This document is in the possession of the corresponding author.

\section{References}

1. Bull MJ, Committee on Genetics. Health supervision for children with Down syndrome. Pediatrics. 2011;128:393-406.

2. Fort P, Lifshitz F, Bellisario R, Davis J, Lanes R, Pugliese M, et al. Abnormalities of thyroid function in infants with Down syndrome. J Pediatr. 1984:104:545-9.

3. Purdy IB, Singh N, Brown WL, Vangala S, Devaskar UP. Revisiting early hypothyroidism screening in infants with Down syndrome. J Perinatol. 2014;34:936-40.

4. Pierce MJ, LaFranchi SH, Pinter JD. Characterization of thyroid abnormalities in a large cohort of children with Down syndrome. Horm Res Paediatr. 2017;87:170-8 
5. Kariyawasam D, Carré A, Luton D, Polak M. Down syndrome and nonautoimmune hypothyroidisms in neonates and infants. Horm Res Paediatr. 2015;83:126-31

6. van Trotsenburg AS, Kempers MJ, Endert E, Tijssen JG, de Vijlder JJ, Vulsma T. Trisomy 21 causes persistent congenital hypothyroidism presumably of thyroidal origin. Thyroid. 2006;16:671-80

7. Lavigne J, Sharr C, Elsharkawi I, Ozonoff A, Baumer N, Brasington C, et al. Thyroid dysfunction in patients with Down syndrome: Results from a multi-institutional registry study. Am J Med Genet A. 2017;173:1539-45.

8. Fialkow PJ, Hecht F, Uchida IA, Motulsky AG. Increased frequency of thyroid autoantibodies in mothers of patients with Down's syndrome. Lancet. 1965;2(7418):868-70.

9. Medda E, Olivieri A, Stazi MA, Grandolfo ME, Fazzini C, Baserga M et al. Risk factors for congenital hypothyroidism: results of a population case-control study (1997-2003). Eur J Endocrinol. 2005;153:765-73.

10. Corona-Rivera JR, Martínez-Macías FJ, Bobadilla-Morales L, Corona-Rivera A, Peña-Padilla C, Ríos-Flores IM, et al. Prevalence and risk factors for Down syndrome: A hospital-based single-center study in Western Mexico. Am J Med Genet A. 2019;179:435-41.

11. Elmlinger MW, Kühnel W, Lambrecht HG, Ranke MB. Reference intervals from birth to adulthood for serum thyroxine (T4), triiodothyronine (T3) free T3, free T4, thyroxine binding globulin (TBG) and thyrotropin (TSH). Clin Chem Lab Med. 2001;39:973-9.

12. Marks AG, LaFranchi SH. Assessing thyroid function in infants and children. In: Brent GA, editor. Thyroid function testing. New York: Springer; 2010. pp. 173-185

13. Jonklaas J, Bianco AC, Bauer AJ, Burman KD, Cappola AR, Celi FS, et al. Guidelines for the treatment of hypothyroidism: prepared by the American Thyroid Association Task Force on thyroid hormone replacement. Thyroid. 2014;24:1670-751.
14. Bennett RL, French KS, Resta RG, Doyle DL. Standardized human pedigree nomenclature: update and assessment of the recommendations of the National Society of Genetic Counselors. J Genet Couns. 2008;17:424-33.

15. Hinton CF, Harris KB, Borgfeld L, Drummond-Borg M, Eaton R, Lorey F, et al. Trends in incidence rates of congenital hypothyroidism related to select demographic factors: data from the United States, California, Massachusetts, New York, and Texas. Pediatrics. 2010;125(Suppl 2):S37-47.

16. Vela-Amieva M, Gamboa-Cardiel S, Pérez-Andrade ME, Ortiz-Cortés J, González-Contreras CR, Ortega-Velázquez V. Epidemiology of congenital hypothyroidism in Mexico. Salud Publica Mex. 2004;46:141-8.

17. Jaruratanasirikul S, Patarakijvanich N, Patanapisarnsak $C$. The association of congenital hypothyroidism and congenital gastrointestinal anomalies in Down's syndrome infants. J Pediatr Endocrinol Metab. 1998;11:241-6.

18. van Trotsenburg AS, Vulsma T, van Santen HM, Cheung W, de Vijlder JJ. Lower neonatal screening thyroxine concentrations in Down syndrome newborns. J Clin Endocrinol Metab. 2003;88:1512-5.

19. Erlichman I, Mimouni FB, Erlichman M, Schimmel MS. Thyroxine-based screening for congenital hypothyroidism in neonates with Down syndrome. J Pediatr. 2016;173:165-8.

20. Zimmerman R, Pal DK, Tin A, Ahsan H, Greenberg DA. Methods for assessing familial aggregation: family history measures and confounding in the standard cohort, reconstructed cohort and case-control designs. Hum Hered. 2009;68:201-8.

21. Underland L, Kenigsberg L, Derrick KM, Crespi R, Kaushal T, Lam L. Thyroid function testing in neonates with maternal history of disease. Clin Pediatr (Phila). 2018;57:436-41.

22. Waller DK, Anderson JL, Lorey F, Cunningham GC. Risk factors for congenital hypothyroidism: an investigation of infant's birth weight, ethnicity, and gender in California 1990-1998. Teratology. 2000;62:36-41. 